\title{
ALK (anaplastic lymphoma kinase, CD246)-specific CARs: new immunotherapeutic agents for the treatment of pediatric solid tumors
}

\author{
Rimas J Orentas ${ }^{1 *}$, Paola Lopomo ${ }^{1}$, William Babbitt ${ }^{1}$, Marc Vigny ${ }^{2}$, Crystal L Mackall ${ }^{1}$ \\ From Society for Immunotherapy of Cancer 28th Annual Meeting \\ National Harbor, MD, USA. 8-10 November 2013
}

The identification of unique cell-surface proteins expressed on tumor cells, yet not expressed on normal tissues, has been challenging for pediatric malignancies. The cell surface tyrosine kinase ALK (CD246, anaplastic lymphoma kinase) is a promising target for neuroblastoma in that it is expressed in either native, mutated, or over-expressed forms on the plasma membrane surface. We identified antibodies that bind to ALK, sequenced their variable regions, and used this sequence information to construct chimeric antigen receptors (CARs). Primary human T lymphocytes were then transduced with retroviral gene vectors expressing a series of ALK-specific CARs, that included different structural and signaling motifs. Transduced $\mathrm{T}$ cells demonstrated ALK-specific cytolytic activity against ALK-expressing tumors and produced Th1 cytokines upon culture in the presence of tumor. In exploring different iterations of CAR protein domain structure we found that the $\mathrm{scFv}$ domains created from the heavy and light variable domains of ALK-specific immunoglobulin could be interchanged with respect to their orientation in the context of CAR tertiary protein structure. Moreover, ALK-specific $\mathrm{scFv}$ functioned whether expressed in a short format, that is as a single domain proximal to the $\mathrm{T}$ cell membrane, or in a long format, that is extended away from the plasma membrane using an IgG1-derived spacer domain composed of $\mathrm{CH} 2$ and $\mathrm{CH} 3$. Using a xenogeneic NSG mouse model for neuroblastoma, human ALK-specific CARexpressing $\mathrm{T}$ cells were found eradicate ALK-positive tumor, when IL-7 was included to support T cell persistence. These data argue for the continued evaluation of ALK-specific CARs in pre-clinical studies.

'Pediatric Oncology Branch, CCR, NCl, NIH, Bethesda, MD, USA

Full list of author information is available at the end of the article

\section{Authors' details}

${ }^{1}$ Pediatric Oncology Branch, CCR, NCI, NIH, Bethesda, MD, USA. ${ }^{2}$ Institut du Fer à Moulin, INSERM/UPMC, Paris, France.

Published: 7 November 2013

doi:10.1186/2051-1426-1-S1-P27

Cite this article as: Orentas et al:: ALK (anaplastic lymphoma kinase, CD246)-specific CARs: new immunotherapeutic agents for the treatment of pediatric solid tumors. Journal for ImmunoTherapy of Cancer 2013 1(Suppl 1):P27.
Submit your next manuscript to BioMed Central and take full advantage of:

- Convenient online submission

- Thorough peer review

- No space constraints or color figure charges

- Immediate publication on acceptance

- Inclusion in PubMed, CAS, Scopus and Google Scholar

- Research which is freely available for redistribution
C Biomed Central 